\title{
Eco-efficiency of passive solar heating
}

\author{
Ksenia Klevets ${ }^{1}$, Alexander Dvoretsky ${ }^{1 *}$ and Alexander Spiridonov $^{2}$ \\ ${ }^{1}$ V.I. Vernadsky Crimean Federal University, 295493, Simferopol, Russia \\ ${ }^{2}$ The Research Institute for Building Physics under Russian Ministry of Construction and Academy of \\ architecture and construction science (NIISF RAASN), 127238, Moscow, Russia
}

\begin{abstract}
The article presents calculations of the energy efficiency of direct solar heating and sunspace, located on the building facades of various orientations, in the climatic conditions of the southern coast of Crimea. The share of compensation for heat losses due to passive solar heating has been determined. The calculation of the environmental effect of passive solar heating systems has been done.
\end{abstract}

\section{Introduction}

In regions with a large amount of solar radiation during the heating period [1-6], it is advisable to use the passive solar heating installation not only to save fossil fuels, but also to obtain a positive environmental effect. The eco-effect of passive solar heating is due to the reduction of $\mathrm{CO}_{2}$ emissions into the atmospheric air, by burning of fuel to heat buildings.

The works [5-10] is devoted to study the passive solar heating. The relationship between energy efficiency and the level of carbon dioxide emissions is investigated in the works $[8,9]$. Improving the energy efficiency of buildings is one of the factors ensuring the biosphere compatibility of cities and settlements [7,11].

\section{Objective and tasks of research}

The object of research is a passive solar heating devices. The purpose of the research is to determine the ecological efficiency of direct solar heating and sunspace on the various facade orientations of a building.

This work is divided in three main parts :

- calculation of the energy efficiency of direct solar heating and sunspace, designed on various facades of the building in the climatic conditions of the Yalta city;

- determination of the compensation share for building heat losses due to passive solar heating;

- calculation of the environmental effect of the most profitable options for the device of passive solar heating.

"Corresponding author: erces crimea@mail.ru 


\section{Materials and methods}

The paper uses analytical methods for calculating heat losses and inputs, as well as calculating the environmental efficiency of passive solar heating, based on construction regulatory documents of the Russian Federation [2-4]. To conduct research on the definition and comparison of the environmental efficiency of passive solar heating, a rectangular building of $10 \mathrm{~m} \times 10 \mathrm{~m} \times 3 \mathrm{~m}$, a floor area of $100 \mathrm{~m}^{2}$, a heated volume of $300 \mathrm{~m}^{3}$ being considered in this article. Two types of devices were chosen: direct solar heating (or a window) and sunspace, which are arranged on different facades of the object. The glazing area of passive solar heating devices is $2.5 \mathrm{~m} \times 4 \mathrm{~m}=10 \mathrm{~m}^{2}$ (Fig. 1). Sizes of sunspace: $2 \mathrm{~m} \times 4 \mathrm{~m} \times 2.5 \mathrm{~m}$, floor area $8 \mathrm{~m}^{2}$.

a

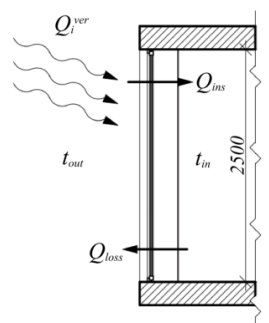

b

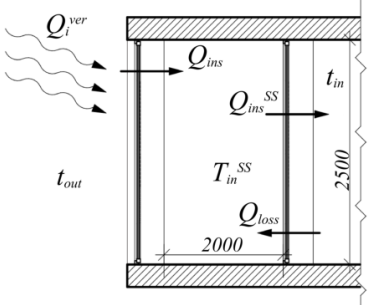

Fig. 1. Solar heating devices: $a$ - direct solar heating; $b$ - sunspace

City of construction is Yalta. Estimated period: November - March. To calculate the heat losses, the heat transfer resistance of the enclosing structures is assumed to be the minimum allowable in accordance with [3]: the heat transfer resistance of walls $R_{\text {wall }}=2.3 \mathrm{~m}^{2} .{ }^{\circ} \mathrm{C} / \mathrm{W}$, floor and ceiling $\mathrm{R}_{\text {floor }}=2.84 \mathrm{~m}^{2 .}{ }^{\circ} \mathrm{C} / \mathrm{W}$. In the designs of devices for passive solar heating, a singlechamber double-glazed window with ordinary glass in wooden window cover is adopted, with heat transfer resistance $R_{\text {win }}=0.35 \mathrm{~m}^{2} \cdot{ }^{\circ} \mathrm{C} / \mathrm{W}$; shading coefficient by opaque elements is $\tau_{1}=0.8$; the relative transmittance of solar radiation is $\tau_{2}=0.76$ [2]. The temperature inside of the heated volume is assumed to be $\mathrm{t}_{\mathrm{in}}=+20^{\circ} \mathrm{C}$, the temperature of the ground is $\mathrm{t}_{\mathrm{gr}}=+5^{\circ} \mathrm{C}$, the average monthly temperature of the outside air is taken in accordance with [4] and shown in Table 1. Indicator of the average monthly total solar radiation entering the vertical surfaces with actual conditions of cloudiness for 1 hour, heat input and heat loss are calculated on the basis of formulas [3], as well as [2] and shown in Table 1.

Table 1. Initial data

\begin{tabular}{|c|c|c|c|c|c|c|c|c|c|c|}
\hline & \multicolumn{8}{|c|}{$\begin{array}{l}\text { Average monthly solar radiation on vertical surfaces with } \\
\text { average cloud conditions for } 1 \text { hour }\left[\mathrm{Wh} / \mathrm{m}^{2}\right]\end{array}$} & \multirow{2}{*}{$\begin{array}{c}\text { Monthly } \\
\text { average } \\
\text { outdoor } \\
\text { temp. } \\
{\left[{ }^{\circ} \mathrm{C}\right]}\end{array}$} & \multirow{2}{*}{$\begin{array}{c}\text { Average } \\
\text { monthly heat } \\
\text { loss through } \\
\text { enclosing } \\
\text { structures } \\
\text { without } \\
\text { passive solar } \\
\text { heating } \\
{[\mathrm{kW} \cdot \mathrm{h}]} \\
\end{array}$} \\
\hline & $\mathrm{N}$ & $\mathrm{NE}$ & E & $\mathrm{SE}$ & S & SW & W & NW & & \\
\hline NOV & 23.6 & 24.8 & 41.2 & 69.7 & 89.0 & 71.2 & 41.2 & 24.8 & +9.5 & 1.45 \\
\hline DEC & 16.7 & 16.9 & 27.5 & 49.7 & 65.3 & 49.7 & 27.5 & 16.8 & +6.3 & 1.73 \\
\hline JAN & 20.6 & 20.2 & 32.1 & 53.9 & 69.7 & 55.8 & 32.1 & 20.6 & $\begin{array}{r}+3.9 \\
\end{array}$ & 1.94 \\
\hline FEB & 32.2 & 32.5 & 47.2 & 67.4 & 82.7 & 70.5 & 46.6 & 32.5 & +4.2 & 1.91 \\
\hline MAR & 50.6 & 53.1 & 78.5 & 98.3 & 109.5 & 101.4 & 78.5 & 53.7 & +6.0 & 1.75 \\
\hline
\end{tabular}




\section{Results and discussion}

\subsection{Calculation of heat input through the construction of passive solar heating devices}

Heat input during direct solar heating, $Q_{i n s}$, Wh, shown in Table 2 and was calculated by the formula:

$$
Q_{\text {ins }}=Q_{i}^{v e r} \cdot \tau_{1} \cdot \tau_{2}
$$

where $Q_{i}^{v e r}$ - average monthly specific total solar radiation arriving on the vertical surface of the $i$-th orientation, under actual cloud conditions in 1 hour, $\mathrm{Wh} / \mathrm{m}^{2} ; \tau_{1}$ - coefficient of shading by opaque elements; $\tau_{2}$ - coefficient of relative penetration of solar radiation.

Table 2. Direct solar heating calculation results

\begin{tabular}{|c|c|c|c|c|c|c|c|c|}
\hline \multirow{2}{*}{} & \multicolumn{9}{|c|}{ Average monthly heat input through direct solar heating for 1 hour [Wh] } \\
\cline { 2 - 10 } & $\mathrm{N}$ & $\mathrm{NE}$ & $\mathrm{E}$ & $\mathrm{SE}$ & $\mathrm{S}$ & $\mathrm{SW}$ & $\mathrm{W}$ & $\mathrm{NW}$ \\
\hline NOV & 143.6 & 150.8 & 250.2 & 423.5 & 540.9 & 432.6 & 250.2 & 150.8 \\
\hline DEC & 101.5 & 102.6 & 167.0 & 302.1 & 397.0 & 302.1 & 167.0 & 102.2 \\
\hline JAN & 125.3 & 122.6 & 195.1 & 327.4 & 423.7 & 339.4 & 195.1 & 125.3 \\
\hline FEB & 195.9 & 197.8 & 287.0 & 409.8 & 502.8 & 428.4 & 283.3 & 197.8 \\
\hline MAR & 307.5 & 322.6 & 477.1 & 597.7 & 665.5 & 616.5 & 477.1 & 326.4 \\
\hline
\end{tabular}

To get into the heated room, the sunlight must pass through two layers of glazing and, therefore, the heat input through the sunspace is calculated by the formula:

$$
Q_{\text {ins }}^{S S}=Q_{i}^{v e r} \cdot \tau_{1}^{2} \cdot \tau_{2}^{2}
$$

It is also necessary to take into account that the average monthly temperature inside an unheated sunspace will be higher than the outdoor air temperature. Sunspace will serve as a buffer room, and therefore the heat loss through the building envelope will be reduced. The temperature inside the sunspace $T_{\text {in }}^{S S},{ }^{\circ} \mathrm{C}$, shown in Table 3 and calculated by the formula:

$$
T_{\text {in }}^{S S}=\frac{\sum t_{\text {out }} \cdot \frac{A_{i}}{R_{i}}}{\sum \frac{A_{i}}{R_{i}}}
$$

where $t_{\text {out }}$ - outdoor air temperature for the building envelope of the $i$-th orientation, ${ }^{\circ} \mathrm{C}$; $A_{i}$ - area of the enclosing structure of the sunspace $i$-th orientation, $\mathrm{m}^{2} ; R_{i}$ - resistance to heat transfer enclosing structures of the sunspace of the $i$-th orientation, $\mathrm{m}^{2.0} \mathrm{C} / \mathrm{W}$. 
Table 3. Sunspace calculation results

\begin{tabular}{|c|c|c|c|c|c|c|c|c|c|}
\hline & \multicolumn{8}{|c|}{ Average monthly heat input through the sunspace for 1 hour [Wh] } & \multirow{2}{*}{$\begin{array}{c}\text { Temp. } \\
\text { inside the } \\
\text { sunspace } \\
{\left[{ }^{\circ} \mathrm{C}\right]}\end{array}$} \\
\hline & $\mathrm{N}$ & $\mathrm{NE}$ & E & SE & $\mathrm{S}$ & SW & W & NW & \\
\hline NOV & 87.3 & 91.7 & 152.1 & 257.5 & 328.9 & 263.0 & 152.1 & 91.7 & +13.8 \\
\hline DEC & 61.7 & 62.4 & 101.5 & 183.6 & 241.4 & 183.6 & 101.5 & 62.1 & +12.1 \\
\hline JAN & 76.2 & 74.5 & 118.6 & 199.1 & 257.6 & 206.4 & 118.6 & 76.2 & $\begin{array}{l}+10.8 \\
\end{array}$ \\
\hline FEB & 119.1 & 120.3 & 174.5 & 249.2 & 305.7 & 260.5 & 172.3 & 120.3 & +11.0 \\
\hline MAR & 187.0 & 196.1 & 290.1 & 363.4 & 404.6 & 374.8 & 290.1 & 198.4 & +11.9 \\
\hline
\end{tabular}

\subsection{Determination of the compensation share for building heat losses due to passive solar heating}

The results of calculations of heat loss of the building using direct solar heating. with a glazing area of $10 \mathrm{~m}^{2}$ on different facades of the building has been shown in Fig. 2. and also, the level of heat loss of the object without direct solar heating.

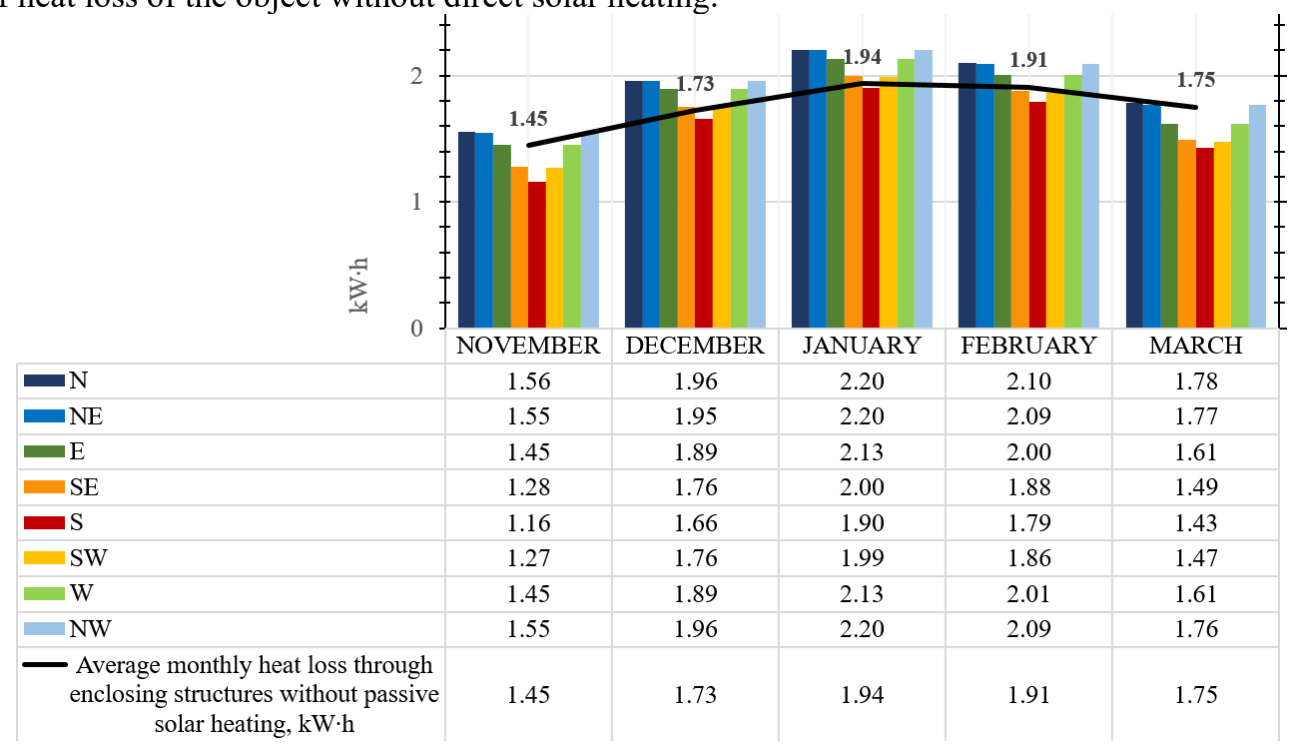

Fig. 2. Heat loss of a building with direct solar heating

A stable positive energy effect from direct solar heating is observed only on the south facade. When direct solar heating is located on other facades a stably negative energy effect is observed (this means that the heat input through the window does not exceed the heat loss through it), and only in November and March does the positive energy effect appear in the SE and SW of the window orientation.

If the direct solar heating structures are located on the southern facade, the share of compensation for the total heat loss of the building with a heated area of $100 \mathrm{~m}^{2}$ will be from $1.7 \%$ in January to $19.8 \%$ in November.

The results of calculations of heat loss of a building with the sunspace, considering the temperature inside it, is shown in Fig. 3. Sunspace with a glazing area of $10 \mathrm{~m}^{2}$ alternately located on different facades of the construction site. 


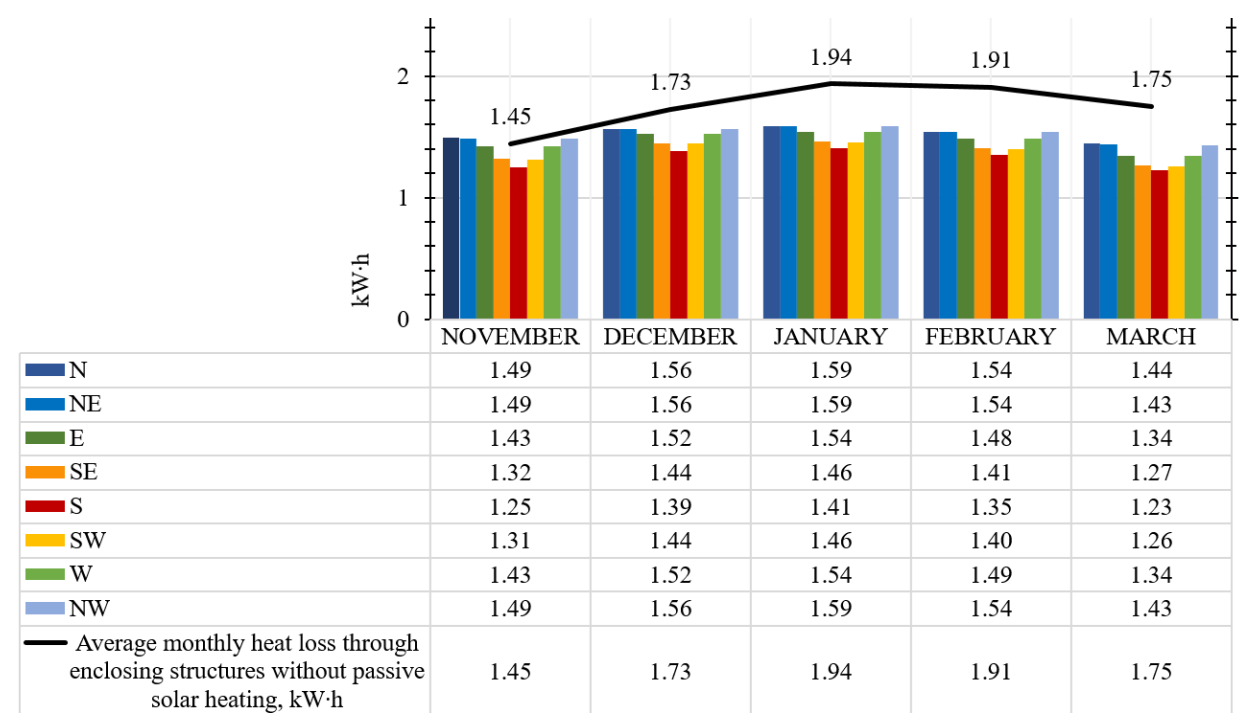

Fig. 3. Heat loss of the building with the sunspace

\subsection{Calculation of the environmental effect of passive solar heating}

The work [8] describes an algorithm for converting the fuel saved by passive solar heating into mass of non-carbon dioxide $\mathrm{CO}_{2}$. Provided that natural gas is used for heating with a three-atom gas volume in the combustion products of gaseous fuel $\mathrm{V}_{\mathrm{rO} 2}$, equal to $1.05 \mathrm{~m}^{3} / \mathrm{m}^{3}$, every saved $\mathrm{kWh}$ of thermal energy reduces $\mathrm{CO}_{2}$ emissions by $2.87 \mathrm{~kg}$. Table 4 presents the results of a monthly reduction in $\mathrm{CO}_{2}$ emissions due to the use of passive solar heating (in Table 4, direct solar heating deals only with south orientation).

Table 4. Eco-efficiency of passive solar heating

\begin{tabular}{|l|c|c|c|c|c|c|c|c|c|}
\hline & \multicolumn{10}{|c|}{ Monthly average $\mathrm{CO}_{2}$ emissions reduction [kg/month] } & $\begin{array}{c}\text { direct } \\
\text { gain }\end{array}$ \\
\cline { 2 - 11 } & \multicolumn{9}{|c|}{ sunspace } \\
\cline { 2 - 11 } & $\mathrm{N}$ & $\mathrm{NE}$ & $\mathrm{E}$ & $\mathrm{SE}$ & $\mathrm{S}$ & $\mathrm{SW}$ & $\mathrm{W}$ & NW & S \\
\hline NOV & - & - & 41.4 & 259.2 & 406.7 & 270.6 & 41.4 & - & 592.2 \\
\hline DEC & 342.9 & 344.3 & 427.9 & 603.3 & 726.6 & 603.3 & 427.9 & 343.8 & 139.1 \\
\hline JAN & 743.7 & 740.2 & 834.3 & 1006.1 & 1131.1 & 1021.7 & 834.3 & 743.7 & 71.9 \\
\hline FEB & 712.7 & 715.0 & 819.6 & 963.6 & 1072.6 & 985.4 & 815.3 & 715.0 & 231.4 \\
\hline MAR & 656.6 & 676.2 & 876.8 & 1033.3 & 1121.4 & 1057.8 & 876.8 & 681.1 & 696.9 \\
\hline
\end{tabular}

\section{Conclusion}

1. Excess heat, and, consequently, a positive environmental effect, in the climatic conditions of the Crimea with direct heating is consistently observed only on the southern facade of the building. The $10 \mathrm{~m}^{2}$ window opening with the simplest design (single-chamber double-glazed window) allows to reduce the total heat loss of a building with a heated area of $100 \mathrm{~m}^{2}$ from 2 to $20 \%$ during the heating period. With SE and SW orientation a positive result is observed only in November. February and March: the heat loss is reduced by $11-15 \%$.

2. Excess heat energy and a positive environmental effect when building has sunspace, with a glazing area of $10 \mathrm{~m}^{2}$ outside and inside, takes place in all months and in any orientation of 
the sunspace, with the exception of the NE-S-NW direction in November. The best result in arranging sunspace on the south facade: cost reduction by $13.6-30 \%$ during the heating period.

3 . In one month of the heating period, direct heating with an area of $10 \mathrm{~m}^{2}$, located on the southern façade, reduces $\mathrm{CO}_{2}$ emissions by $70-690 \mathrm{~kg}$.

4. Sunspace, located on the southern façade, leads to a reduction in $\mathrm{CO}_{2}$ emissions of 400$1100 \mathrm{~kg}$ per month.

Due to the fact that translucent structures have high thermal conductivity, their presence in the construction site leads to an increase in heat loss of the building (even taking into account the higher temperature inside the sunspace compared to the outdoor air temperature). Taking into account passive solar heating, translucent structures become sources of heat, as well as a way to save fuel and, accordingly, reduce $\mathrm{CO}_{2}$ emissions.

To obtain the maximum effect, both direct heating and sunspace should be located on the southern facade of the building. This causes the device sun protection for the hot period of the year. It is worth noting that sunspace in all senses is a more advantageous solution. Firstly, a positive effect from sunspace in the months of the heating period is observed at any orientation, which makes it possible to use it, for example, when reconstructing existing buildings in order to increase their energy and eco-efficiency. Secondly, the sunspace itself is the sun protection element of the building. In the summer months, when the angle of incidence of sunlight at noon reaches its maximum value, the roof structure of the sunspace cuts off these rays, preventing them from entering the living quarters. For thermoregulation of indoor air in a sunspace, it is enough to open the outer glazing.

This article was designed in response to the project co-funded by the Research Institute for Building Physics, Moscow, Russia.

\section{References}

1. D.A. Bainbridge, K. Haggart, Passive solar architecture. Heating, cooling, ventilation and daylighting using natural flows (Chelsea Green Publishing, USA, 2011).

2. Building Regulation (2004), SP 23-101-2004 Design of the thermal performance of buildings. Moscow, FGYP CCP, (In Russian).

3. Building Regulation (2012), SP 50.13330.2012 Thermal performance of buildings, Moscow, Minregion Rossii (In Russian).

4. Building Regulation (2015), 131.13330.2012 Building climatology. Moscow, Minstroi Rossii, (In Russian).

5. A.T. Dvoretsky, K.N. Klevets, Passive solar heating of building, Biospheric compatibility: human, region, technologies, 3 (11), 85-91 (2015)

6. A.T. Dvoretsky, A.V. Spiridonov, M.A. Morgunova, Influence of Russian Federation climate and the orientation of the building for selection of stationary solar shading devices, Biospheric compatibility: human, region, technologies, 4 (16), 50-57 (2016).

7. V.A. Ilyichev, S.G. Yemelyanov, V.I. Kolchunov, N.V. Bakaeva, Innovative technologists in the construction of cities. Biosphere compatibility and human potential (Moscow, Russia, 2019).

8. K.N. Klevets, Comprehensive assessment of the environmental safety of passive solar heating devices, Construction economic and environmental management, 3 (68), 9-18 (2018).

9. S. Koller, German experience in improving energy efficiency in the building sector: proceedings of the report at the meeting of the subgroup on energy efficiency of the 
Russian-German strategic working group for cooperation in the field of economics and finance, (2013).

10. Passive Solar Industries Council (U.S.), National Renewable Energy Laboratory (U.S.), Charles Eley Associates, (1998), Passive Solar Design Strategies: Guidelines for Home Building, Passive Solar Industries Council, USA.

11. O.V. Sergeichuk, Energy efficiency of buildings as a factor in the biospheric compatibility of cities, Budownictwo o zoptymalizowanym potencjale energetycznym, 1 (19), 110-117 (2012). 